\title{
Development of Society under the Modern Technology- A Review
}

\author{
Aasif Ali Naikoo ${ }^{1}$ \\ Shashank Shekhar Thakur ${ }^{2}$ \\ Tariq Ahmad Guroo ${ }^{3}$ \\ Aadil Altaf Lone ${ }^{4}$ \\ ${ }^{1,3,4}$ Research Scholar, Department of Sociology and Social Work \\ ${ }^{2}$ Assistant Professor, Department of Sociology and Social Work \\ Barkatullah University, \\ Bhopal-462026, (M.P) 462026
}

\begin{abstract}
The main objective of the present study is to know the relationship between society and technology, where emphasize have been put on development process under modern science and technology and its perspectives. Technology has completely revolutionized present era in every aspect of life especially dealing with society. Technology has transformed the methods of education, communication, business, art and literature, and has resulted in the enhancement in the core spheres of life, before this blessed gift the knowledge regarding the above mentioned spheres was limited because of the restricted methods and methodologies etc. Due to blessings of science and technology we are now able to check the advancement of every department working around our society with a single click of internet. It is technology which helps us to differentiate about the development process of all sections of society and help us to maintain the development process. Technology has brought our society close to each other where we can take any initiative about any social issue or discuss any matter of concern regarding the society by sitting in our homes like using video or audio conferencing. This paper will elucidate all over development process of our society under the shades of science and technology.
\end{abstract}

KEY WORDS: Society, Science, Technology, Development.

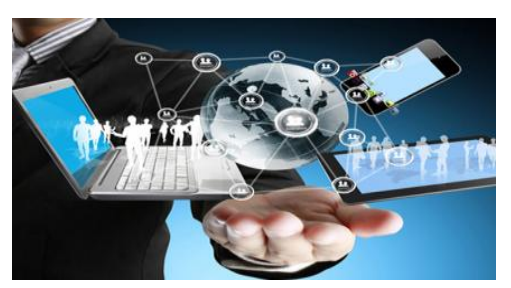

\section{Introduction:}

As a whole science and technology is having a great impact on society. The incorporation of such blessings in society is having a great influence on social interaction. It is apparent from the existing knowledge that new technologies brunt on the social communication within households in many different ways. Technology has bought the new methods of communication which made us easy to identify and interact with someone who is known or unknown on universal level. Science and technology is playing a role of bridge for the rural upliftment and social development. It is technology which transformed the human race from Stone Age to modern industrial age. Science and technology not only influenced our communication method but also enlightened our rural economy by its modern agricultural methods. Modern technology and scientific tools enhanced the economic growth of the country and made every impossible work an easy task to handle. It is technology which impacts globally the social life and provides opportunities for every social person to become conscious about society and to achieve societal goals. The word technology is combination of two words "Techno and Logy" (Techno) means art, application or skill and (Logy) means science and learning. It means technology is the way of methods and tools that a society has created in 
order to make possible solutions of present problems and to provide essential demands for the community. Nowadays relationship has become too much dominated by the use of modern technology like social media, which reduced the distance and brought the society close to each other. Technology is recognized as the indicator of social and cultural awareness because it has improved the quality of life and developed the cultural assets in the community. Science and technology has a great impact on education system of society. As we know education is the important area of life, the modern technological methods made our education system not only good but also provide us knowledge of unknown facts which were beyond the imagination of human mind. (Younis, M.B, 2015)[1] Science and technology has a great impact on labour industry, in the past labours had to suffer too much in performing any task but due to the use of technology labours earn more in shorter period of time and by easy methods which led the positive impact in their lives. Technology has brought a revolution in every aspect of social life; machines are working instead of humans who have a great tendency to perform tasks with accuracy and performance. It is technology which is used to identify any kind of problem in the human body and not only to identify but also are these problems cured with proper treatment. All human activities are influenced by technology like transportation, housing, nutrition, work, leisure, even art and imagination. Science and Technology is seen as organized search for truth and objective knowledge, because science tells us the reality behind any process and also aware us about the improper use of any substance which is dangerous for human life. So, it affects directly our social life. Technology helps us to use modern skills and modern equipments to perform any task within less time and with proper results. if we look towards our daily lives we use technology at every point of time the blessings like T.V, radio, computer, washing machines, microwave ovens, ATM, trains, airplanes, cars, mobiles, etc are all means of technology. So, our social life is totally dependent on science and technology. (Khulaifi, M, 2002) [2]

\section{Review of Literature:}

${ }^{[1]}$ Al- Majali (2007) [3] Analyzed in his study "impact of internet use on the social relations among university students in Jordanian society". During his study he took 325 respondents for the study purpose from Mutah University. The study shows that social relations increased and people came close to each other due to the use of internet and students spend too much time on internet. The study also shows that students use internet mostly for the research purpose and mostly they use it within the campus.

${ }^{[2]}$ Lailah (2000) [4] conducted a study on the negative impact of media and information technology in our society. This study helps to erode the value system which tilting to family interaction. This study also helps us to understand and aware us in upbringing the young and adult ones in a moral way which will help in supporting their identity.

${ }^{[3]} \mathrm{Al}$ Yousef (2006) [5] carried out a study on "Advantages and Disadvantages of Modern Technologies -in this study he reported negative impact on different parameters of health of an individual by the excessive use of e-mass media . The study realized that addiction of internet will lead to different losses such as: Loss of self control, negligence of personal status, wastage of time and avoidance of relations. According to this study people who get free access of internet are most risky towards internet addiction. Students are even misusing modern technology which has negative impact on their lives. This study was carried out to check the negative impact of modern technology and make people aware about its proper utilization because technology plays an important role in the lives of people and society as a whole.

${ }^{[4]}$ Venkatesh and Vitalari (1985) [6] analyzed a research that shows technology has affected the life of a household by different means and it has become a basis for future social behavior. Technology has emerged a new faces in families and also in individuals life. Technology has changed the structure and function of social system. One of the main impact of technology is found on social interaction between family members and individuals and also the way of communication between them.

${ }^{[5]}$ Irfan et al (2006) [7] conducted a research on role of mass media in the dissemination of agricultural technologies among farmers. This study shows the available technologies, if adopted by farmers according to the recommendations of agricultural scientists. it will enhance the rate of production and can also increase the capital income. According to this study there is an essential need of implementing technological and scientific tools and techniques in the modern agricultural sector for the betterment of farmers. 
${ }^{[6]}$ Siobhan McGrath (2012) [8] analyzed a study based on impact of new media technologies on social interaction in the households. This study analysis that new media technologies like computer, television, mobile phones and other types of modern technologies have influenced the human life with a huge impact. The study also reveals that our day today life is totally dependent on modern technology and it has made the easy possible ways of social interaction.

${ }^{[7]}$ Mohammad Bin Younis et.al (2015) [9] carried out a study on impact of technology on society a review: this study analysis that modern technology is misused by the members of society which lead the negative impact on economics ,religious and social aspect of human behavior. This research also focuses our attention towards society and also it aware us that society should make cooperative efforts in order to protect the entire society from the dangerous of modern technology.

\section{Research Methodology:}

This study is basically descriptive and analytical in nature. In this study an attempt has been made to analyze the development of society under modern technology. This study is based on secondary data such as reports and articles which are published in books, magazines and journals. Online lectures and awareness programmes on T.V and Radio were also utilized by the researcher during the preparation of this article. At theoretical level efforts were made to collect the related material regarding the research article. The whole study revolves around science, technology and society and this study shows the development of society under modern technology. This research contains some reviews of already published articles and books which were published in relation with this article. The available literature regarding the development of society under modern technology has been discussed out to get a clear understanding of our selected research problem. So the researcher tries his best to carry out the study in an appropriate way. In this paper the main stress has been given on the literature of India and its neighboring countries.

\section{Objectives:}

- To know the impact of science and technology on education.

- To know the impact of science and technology on Agriculture.

- To know the impact of science and technology on Environment.

- To know the impact of science and technology on Communication.

- To know the impact of science and technology on Health and hygiene.

- To know the impact of science and technology on Infrastructure.

- To know the impact of science and technology on government and it's planning.

India is the $2^{\text {nd }}$ most populous country in world after china which is a big challenge for the society to overcome from such issues. To neutralize such issues science and technology is the main blessings to fulfill the needs of people and to make healthy environment for social beings. In India more than $70 \%$ of the population resides in the rural areas, inputs of science and technology in agriculture, irrigation, water management, education, health, energy, industry, transport, communications, employment generation, housing, etc. are crucial. The size of the land holdings is very small and becoming smaller with increase in population; technological inputs are therefore, essential, to increase productivity and economic viability.

\section{Impact of science and technology on education:}

Fig. 1- Online lectures

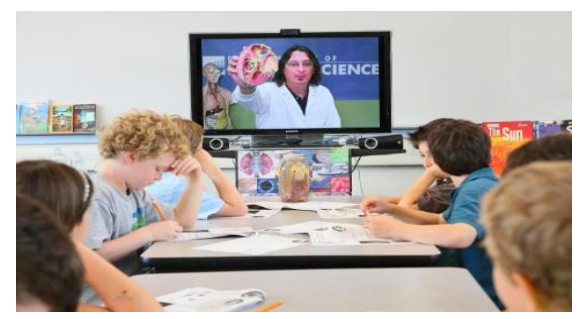

Development of society is recognized by the development in the field of education. Science and technology has brought revolution in the education system and opened the new era of education where you can learn each and every thing by the modern techniques. The present education system reflects a system of standards from the past. Technology is being used by students on daily basis such as web surfing, texting, email, etc. By the use of modern 
technology students can listen and watch best lectures on audio and video conferencing. In modern time education system is blind without the use of internet because internet helps us to make the education more purposeful and more interesting. (Baytak, A, Tarman, B, \& Ayas, C. 2011) [10], Students can download the research articles, books, journals, Magazines and can check the status of their research articles, their application forms, their results, etc. in modern time technology has made our education system open and our knowledge is based on real facts. Science helps us to discover new techniques which bring the modernization in education system and students use these techniques and technologies to work fast and with accuracy. Technology helps us to calculate faster than human mind. It is also used by students to magnify the small objects which we cannot see with the human eye during any experiment process. Finally we can say that modern science and technology is the back boon of education system and also government should facilitate each and every institute with such modern techniques to make the education system more rational and verifiable. (Christen 2009) [11]

\section{Impact of science and technology on agriculture:}

Fig. 2- Modern methods of agriculture

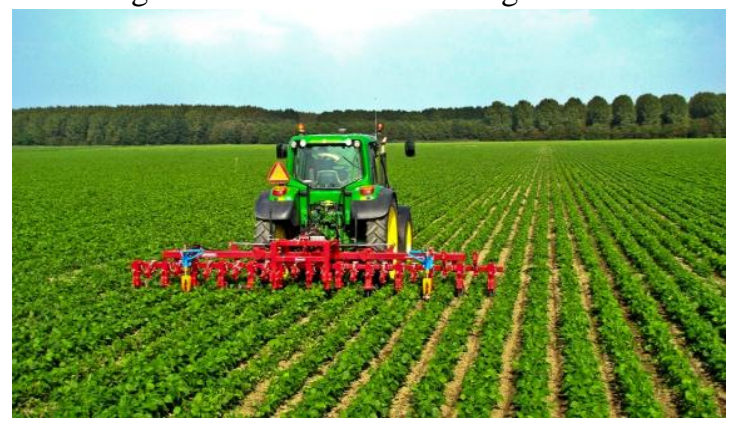

India is an agricultural country in which $72 \%$ of population belongs from rural India whose main occupation is agriculture. Science and technology has a great impact on agricultural sector. it has a significant impact like irrigation systems, tractors, water pumps, electricity, best quality seeds, cold stores, fertilizer applications, weather update, pesticides, fungicides, spray motors, etc optimizes the farmers efficiency and such applications save time and money to the farmers. By the use of modern technology our agricultural economy and food supply got increased which led the positive impact on farmers and on the national economy. (Abbas, et al, 2013)[12] In modern time technology made it possible to grow crops even in a desert by use of agricultural biotechnology. This type of technology has been engineered to survive plants in drought conditions. Crops are being made resistant to draughts and pests by introducing traits into existing genes of plants through genetic engineering. Modern agricultural techniques help a little land holder farmers to cultivate vast quantities of food and yarn in shorter period of time. Modern transportation helps farmers to make food stuffs available on market in time from the farm and also helps them to transport fertilizers or other farm products from one place to another. Under modern technology farmers mix nutrients in water in order to improve the quantity of crops. Technology brought the revolution in agriculture and it still needs more to do in this field to save the life of farmers and also to increase the economic growth of our country. (Behrens, et al, 1984)[13].

\section{Impact of science and technology on environment:}

Fig.3 - Solar energy the eco-friendly form of energy.

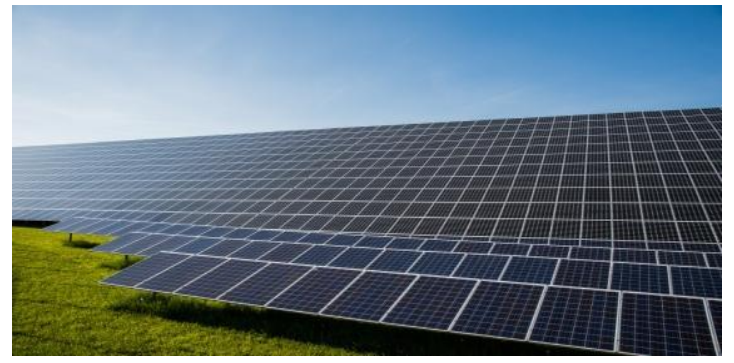

Technology has affected all the aspects of social world, environment is one of them. A good environment belongs to a good society. In modern time people of India suffer too much by the environmental pollution which has become 
the big social issue because people are not using the proper methods of modern technology to protect the social environment. Modern technology is the main power to preserve the natural habitat because technology has provided us such tools which help us to check the levels of environmental pollution such as: water pollution, soil pollution, noise pollution, air pollution, etc. Technology aware us about the life cycle of a product and its consequences on environment. Technology helps in analysis of raw materials that need to be mined or grown and aware us how to disposal the products which are no longer needed. Computers optimize industrial processes to conserve energy and to reduce waste. By the help of technology solar energy is being used which is pollute less and long lasting source of energy. In past trains were using coals as the main fuel which was producing large amount of carbon monoxide which is a harmful gas but by the modern technology electricity is used instead of coal which produces more energy and also it is free from pollution. The used materials like rubber, plastic, steel, iron, paper and water etc are recycled and used again and again to conserve energy and to protect environment from degradation. Infrastructure and development under technology made a positive impact on our society such as: water supply tanks, sewage lines, mecdamization of roads, public gardens and fitness centers are all important aspects of social life and add the beauty of our environment. People should use modern techniques in proper way to protect the environment from pollution. (Adam, Nov. 2011)[14]

\section{Impact of science and technology on communication:}

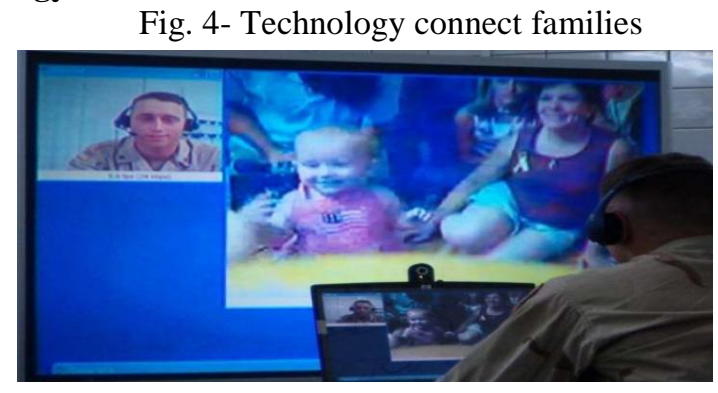

Communication is the important tool of modern life. The world becomes global village with the advancement of science and technology especially in information technology. Science and technology has brought the enlightenment in methods of communication of modern time. People are becoming more dependent on communicating with society and family through different channels of modern technology. World is moving fast towards development and people have less time to talk face to face and to visit one anothers residence so they use modern technology to overcome from these time consuming processes. From the innovation of the telegraph and telephone to the arrival of the Internet, technology has provided tools to keep people in touch with each other and also express and share their feelings and opinions with others. Mobile phones not only help us to listen ones voice but also we can watch them during call. (Emile, 2015) [15], We can also use social networking sites for announcement of social issues and other awareness programmes. Technology improves the quality of communication and it is helpful for the society by every means. This can be fruitful in politics and activism. Such as, photos and video clips recorded secretly through a cell phone can be speedily shared online through websites such as YouTube, face book, twitter and whatsapp. These social networking sites are being used as a tool for protest. For any social development or social control technology is the standard key to bring revolution in social communication. (Campbell, et al, 2011) [16].

\section{Impact of science and technology on health and hygiene:}

Fig.5- Treatment under modern technology

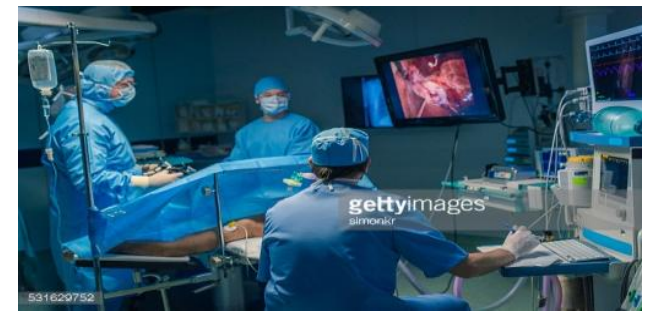

http://dx.doi.org/10.19085/journal.sijbpg050101 
Advanced technology is applied in many areas of healthcare for diagnosis as well as for medical therapy. Medical Technology is the use of scientific knowledge to improve the health care by new equipment to make work easier, pleasant, quick and productive. Now, in modern hospitals, technologists and biomedical engineers are involved in routine day to day work, research and look after the technical development. The rise in life expectancy, in particularly the decline in infant mortality, remains some of the most impressive achievements of modern technology. The invention of modem antibiotics led the positive impact on human health. Decline of the mortality rate and controlling population contraceptives are the blessings of modern technology which balances the social setting in the world. Modern technology and scientific methods are used by households to control the diseases and to check the nutritious food used for good health. Fitness centers are being used on the basis of modern technology to shape the body into a perfect look. Under the modern technology filtrate plants are being constructed to provide the quality water to the residents and also government use to grow plants and flowers of different species around the residential colonies to convert them into hygienic atmosphere. Health is an important component of life and it is modern technology which helps us to select proper food, proper nutrients, proper calcium and other necessary requirements for healthy human body. Healthy body produces healthy mind and healthy mind creates innovations which becomes the building block of technology and finally technology helps in social development. The introduction of any new technology in medical science must provide better health care and improved quality of life at affordable expenses without losing human touch. (Timothey, Jan., 1996) [17]

\section{Impact of science and technology on Infrastructure:}

Fig. 6- India under modern technology

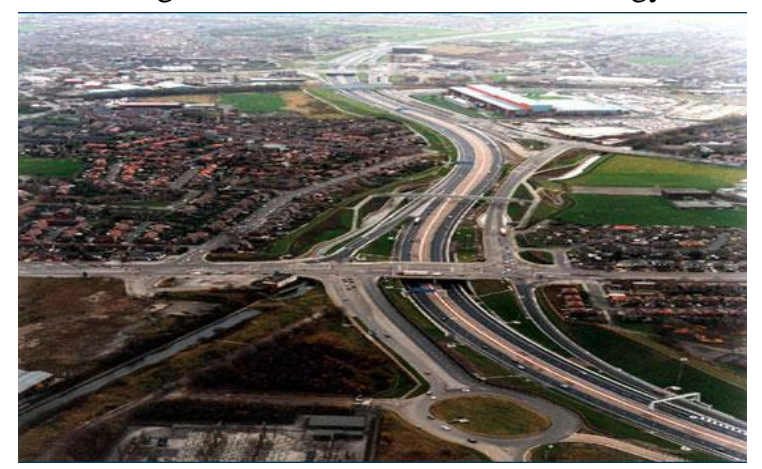

Infrastructure is the basic unit of development. Modern technology has provided the basic assets for the developing infrastructure. Developed countries are recognized by solid infrastructure so it is necessary for the country to become modern in means of infrastructure. Our country is also moving towards a big change in the form of infrastructure and it has covered almost all the necessary requirements of society such as roads, flyovers, bridges, hospitals, education institutions, proper housing colonies, public parks, play grounds, public toilets, airports, railway tracks, shopping malls, vehicle parking zones, proper arrangement of domestic garbage, plantation around the roads, national parks, etc for the public welfare. Technology is becoming a most important part of the infrastructure in developed and developing countries. Proper infrastructure makes a proper way for the people of country to adjust in the society and to adopt the proper social setting. Under the modern technology transportation services work faster as compared to the past due to the working of modern technology on its right base. Infrastructure strategy should not only be deeply informed and influenced by the impact and emerging potential of technology, but should also be based on solid evidence and good advice about what's possible. The gradual move from using infrastructure in existing and new traditional infrastructure assets and using the disruptive potential of cloud-based, technology enabled infrastructure services will not be without its challenges. This is especially true as the new opportunities to lift the performance and impact of infrastructure through wider use of technology meets resistance from current procurement systems and cultures. (Dr. Ken, 2012) [18]

\section{Impact of science and technology on Government:}


Fig. 7 - Technology becomes mediator between government and society

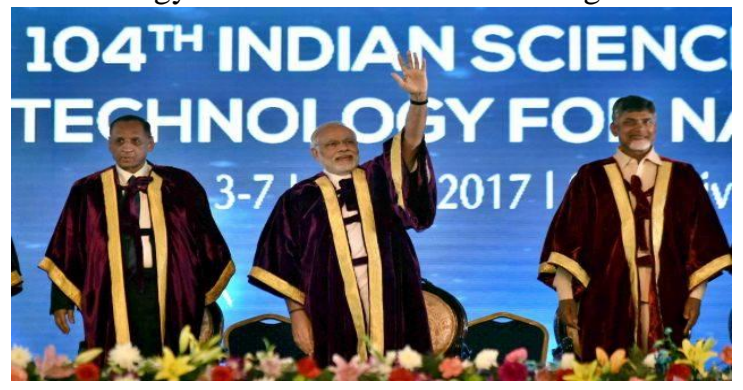

Government at local levels is facing challenges posed by increased demand for better quality of governance. While the developed world and some Asian countries have moved very quickly, under the modern technology every sector of government is empowered through E-Governance. Modern technology helps the government to take every unit of society under their vigilance and for their better services. (http://www.nber.org/chapters/c6067) [19], The country is reached on transitional stage and people are getting benefits from these services. The most popular services like, eeducation, e-court, e-police, e-transport and e-tax etc. The impact of E-Governance has also been observed in rural part of India where services like "Rashtriya Krishi Vikas Yojana", "Kisan Call Centre" etc are more popular. India continues to lag behind in meeting the increasing levels of citizen expectations. (Welch, 2015) [20], The massive population growth, diversity of cultures, acute poverty and high illiteracy create numerous difficulties in delivery mechanisms of government services. The existing processes of service delivery and governance need to be improved. E-governance is the effective use of Information \& Communication Technology (ICT) to improve the system of governance that is in place, and thus provide better services to the Citizens. E-Governance is considered as a high priority agenda in awareness and development of nation. E-Governance has been recognized as a vital force for transformational improvement in quality, efficiency and effectiveness of governance. The Good Governance involves increased participation of the citizens, greater accountability and transparency in the operation of these government bodies. (Monika, april-2014 [21].

\section{Conclusion:}

This research article draws light on the development of society under the modern science and technology. In this research paper we onlooker, that in what ways the modern science and technology are beneficial to society. Technology has influenced our day to day life at every step and we have become dependent on modern tools of technology. Technology has blessed us with priceless gifts which were beyond the human imagination. Technology has done wonders in every field whether it is education, agriculture, communication, health and hygiene, transportation, environment, infrastructure and Governance. It has brought the revolution in the social process and made our life so connected with every part of the globe. Science has made the innovations which check the necessary requirements for human health and social environment. Our resources like water, soil, air, forests and wild life are prevented from any pollution by the modern means of eco- friendly technology. Our society is followed by the different revolutions like green revolutions, white revolution, etc all these revolutions have a positive impact on our society. Technology has made the working process so fast and every action is processed in sharp period of time. It results in saving the time and money which is a big achievement for the people living in the society. Developed countries run each and every thing on technology that is why they are becoming more and more developed. Technology has transformed the old methods of education, art, literature, treatment, communication and skills into the new shape which brought the light of development in modern society. Our country is also moving fast towards development but it still needs a lot to do in every aspect of technical field and other sectors of national developmental services. In order to save social environment people should use modern technology as per the guidelines of government and should take responsibility in shaping the society towards a great development.

\section{Link contains a video which shows how technology revolutionized our society and how it can affect our social environment if not used properly.}

\section{Limitations of the study:}

\section{https://youtu.be/sS-q7yxNMuM}

Technology should be used only for the betterment of the study not to make nuclear powers which has destroyed so many human races and so many species. Government should ban on porn sites which affect the lives of young ones 
and force them to commit any anti-social behavior. Such products should be used which can be recycled and which are not harmful to the society, so that natural resources should be preserved and our natural habitat will maintain balance. We should take benefit of technology but we should not become dependent on technology. Such as to walk a distance of 100 meters we use vehicles which makes us lazy and affects our human health. Social sites should be under surveillance of Government so that they should be used for public awareness not to raise disputes

\section{References:}

[1] Younis, M.B. \& Samier al-zoubi.( 2, feb. 2015) The impact of technology on society : A review - ISQR journal of humanities and social science (ISQR-JHSS) volume 20, issue (pp82-86).

[2] Khulaifi, M, (2002) the impact of the internet in the community: A field study, Alam Al Koteb, 22(5) and 6, pp. 469502.

[3] Al-Majali, F. (2007) The use of the Internet and its impact on social relations among university students, An Empirical Study, lighthouse, 13(7).

[4] Lailah, A.(2009) The role of mass media and information technology in the family disruption: monitoring the movement of the reaction from the center to the margin. Scientific Conference: media and challenges of the times, Cairo University, Faculty of Information, p. 23.

[5] Al Youssef, S. (2006) Modern technologies advantages and disadvantages of a study of the negative effects on the health of the individual, The Book of the nation-Qatar, No. 112, twenty-sixth year, the first edition.

[6] Venkatesh and Vitalari (May, 1985) Computing in the home shifts in the time allocation patterns of households, Communication of ACM, vol. 28, 5, pp.512-522.

[7] Irfan, M., Sher, M., Khan, G. A, \& Asif, M. (2006) Role of mass media in the dissemination of agricultural, International journal of agriculture and biology, 8 (3), pp.117-119. http://www.fspublishers.org [accessed 15 Nov., 2017].

[8] Siobhan, M.G, Siobhan M, G. (2012) The impact of new media technologies on social interaction in the house hold, Electronic culture and social change $3^{\text {rd }}$ year sociology.

[9] Younis, M.B, \& S, A, zoubi, (2015) The impact of technology on society: A review - ISQR journal of humanities and social science (ISQR-JHSS) volume 20,(2) feb., pp 82-86.

[10] Baytak, A, Tarman, B, \& Ayas, C. (2011) Experiencing technology integration in education: children's perceptions. International Electronic Journal of Elementary Education, 3(2), 139-151.

[11] Christen, A, (2009) Transforming the classroom for collaborative learning in the 21st century. Techniques: Connecting Education and Careers, 84(1), 28-31.

[12] Abbas, M., A.D. Sheikh, S. Muhammad \& M. Ashfaq, (2003) Role of electronic media in the adoption of agricultural technologies by farmers in the central Punjab- Pakistan. Int. J. Agri. Biol. Vol. 5 (1), pp. 22-25.

[13] Behrens, J.H. \& J.F. Evans, (1984) Using mass media for extension teaching. In Swanson, B.E. (ed.), Agricultural Extension: A reference manual, FAO, Rome, Italy, pp. 144-155.

[14] Adam B, (Nov-2001) [Discussion paper 00-47 rev], Technological change and the environment, Resources for the future.

[15] Emile, D. (2015) The effect of communication on face to face communication, The Elon journal of undergraduate research in communication, $6(1)$ - spring.

[16] Campbell, S.W., \& Kwak, N. (2011) Mobile communication and civil society: Linking patterns and places of use to engagement with others in public. Human Communication Research, 37, pp. 207-222.

[17] Timothey, F.B \& Robert, J.G, (January-1996) The Economics of New Goods, University of Chicago press Vol. 0-22607415-3, pp. 01-26.

[18] Dr.Ken, H. (2012) Austrialias future prosperity depends on the infrastructure systems, Technology and infrastructure internet business solutions group (ibsg), cisco systems.

[19] http://www.nber.org/chapters/c6067. [accessed, 20 Nov., 2017].

[20] Welch, E. W., Hinnant C. C. \& Moon M. J.(2005) Linking Citizen's Satisfaction with e-Government and Trust in Government," Journal of Public Administration Research and Theory, 15(3), pp. 371-391.

[21] Monika P. \& Gagandeep, K. (Monika, april-2014) Impact of E-governance on public sector services, International journal of emerging research in management and technology, 3(4). 